\title{
THE LIMITS OF DERIVATIVE ACTIONS: THE APPlication OF Limitation Periods TO DERIVATIVE ACTIONS
}

\author{
ROBERT W THOMPSON, QC, ${ }^{*}$ SCOTT T JEFFERS, ${ }^{* *}$ \\ AND CODIE L CHISHOLM ${ }^{* * *}$
}

\begin{abstract}
Limitation periods are an integral and significant aspect of the litigation process in Canada. Although the application of limitation periods may often seem harsh, they are generally considered to be beneficial by bringing stability to society and by providing an incentive to plaintiffs not to "sleep on their rights." However, in corporate derivative actions (actions brought by a shareholder against directors or officers of the corporation on the corporation's behalf), the application of a limitation period presents certain issues that could result in such goals not being advanced. Specifically, two main issues arise, namely; who is the claimant for the purposes of limitation periods, and how do limitation periods apply to leave applications? The authors propose that the Canadian judiciary should adopt the adverse domination doctrine, applying the majority test, and explicitly hold that the filing of the leave application is sufficient to bring the derivative action within the limitation period. This approach would be consistent with the separate corporate existence principle and the purposes underlying limitation periods, as well as providing certainty and predictability to the adjudication of derivative action claims.
\end{abstract}

Les délais de prescription sont un aspect intégral et important du règlement de litiges au Canada. Bien que l'application des délais de prescription semble souvent sévère, on estime généralement qu'ils sont bénéfiques pour apporter une stabilité à la société et éviter que le plaignant ne «dorme sur ses droits ». Cependant, dans le monde des actions dérivées des entreprises (actions lancées par un actionnaire contre les administrateurs ou les dirigeants d'une entreprise au nom de cette entreprise), l'application de ce délai de prescription soulève quelques questions qui risquent de compromettre les progrès vers l'atteinte des objectifs. Deux questions surgissent tout particulièrement, notamment qui est le plaignant pour les besoins des délais de prescription et de quelle manière ces délais s'appliquent-ils aux demandes d'autorisations?Les auteurs suggèrent que les tribunaux canadiens adoptent la doctrine appelée adverse domination, en appliquant l'épreuve de la majorité et en insistant sur le fait qu'il suffit de déposer la requête pour que l'action dérivée soit considérée dans le délai de prescription. Cette démarche serait conforme au principe d'une entité constituée en société en tant que personne morale indépendante, à la raison d'être des délais de prescription et assurerait une certitude et prévisibilité quant à l'adjudication des demandes d'actions dérivées.

\section{TABLE OF CONTENTS}

I. INTRODUCTION . . . . . . . . . . . . . . . . . . . . . . . . . . . . . . 604

II. THEORETICAL CONCERNS WITH LiMitATION PERIODS

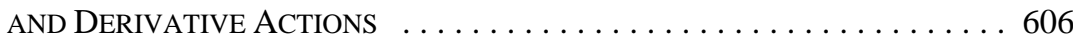

A. Applicable LegisLation . . . . . . . . . . . . . . . . . 606

* $\quad$ Robert W Thompson, QC, is a Partner in the litigation department of Bennett Jones LLP, Calgary, Alberta. He has been involved in all levels of civil litigation, including trials, appeals, and numerous appearances before the Supreme Court of Canada. His practice includes experience in commercial, tort, energy, and education litigation.

** Scott T Jeffers is an Associate in the corporate department of Bennett Jones LLP, Calgary, Alberta. He practices corporate and commercial law with an emphasis on public market transactions, including debt and equity financings and mergers and acquisitions.

*** Codie L Chisholm is an Associate in the litigation department of Bennett Jones LLP, Calgary, Alberta. She has a general commercial litigation practice. 

B. INTERPRETATION OF THE RELEVANT LEGISLATION
AND THE CANADIAN EXPERIENCE $\ldots \ldots \ldots \ldots \ldots \ldots \ldots \ldots 6 . \ldots \ldots$
C. AMERICAN Authorities - THE DEVELOPMENT AND
APPLICATION OF THE ADVERSE DOMINATION DOCTRINE . . . . . 615
D. Proposed Canadian Approach $\ldots \ldots \ldots \ldots \ldots \ldots \ldots \ldots . \ldots 622$

III. PRactical Concerns Within Limitations Periods

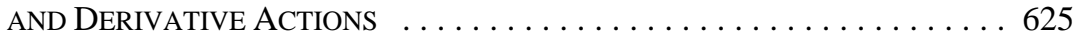

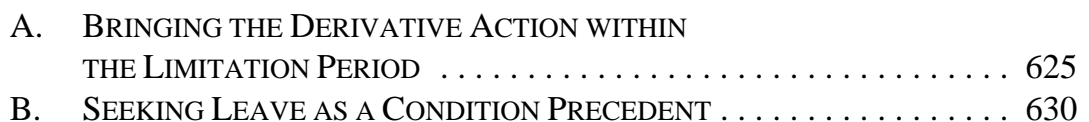

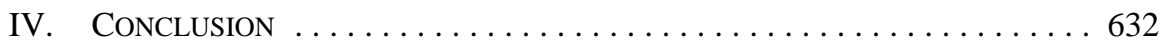

\section{INTRODUCTION}

Limitation periods have long been an integral and significant aspect of the litigation process in Canada, which is due in large part to the ability of limitation periods to singlehandedly preclude actions from being pursued successfully against an otherwise liable defendant. Although this result can often seem harsh, limitation periods are generally considered to be beneficial by bringing stability to society and providing an incentive to plaintiffs not to "sleep on their rights." The operation of limitation periods, however, must be questioned in those instances where these goals are not advanced.

One instance where such a concern arises is the application of limitation periods to corporate derivative actions. In its simplest terms, a derivative action is an action that is brought in a corporation's name, with leave of the court, yet is commenced by a shareholder or creditor (usually referred to as complainant in the business corporation legislation) on behalf of that corporation. A derivative action arises when a corporation has suffered injury at the hands of its directors and officers or others, but the directors and officers refuse to cause the corporation to commence the appropriate legal action, which in most cases would be against themselves.

As will be discussed in greater detail below, two main issues arise when limitation periods are applied to derivative actions. The first relates to when the corporation discovers the elements of the action and whether it is the knowledge of the directors and officers or the knowledge of the complainant that is relevant. The second issue relates to the application of the limitation period to the two-stage process; the first stage being the leave application and the second stage usually being the filing of the statement of claim.

In respect of the first issue, it appears that Canadian courts have calculated the limitation period based on when the complainant discovered the elements of the action, without a discussion of whose knowledge is relevant under the legislation. Further, if the complainant's knowledge is found to be relevant to the corporation's discovery of the elements of the action, then the same claim can result in two different limitation periods applying depending on whether the corporation or the complainant brings the action. This finding is not only

$1 \quad$ Novak $v$ Bond, [1999] 1 SCR 808 at para 8 [Novak], citing Peixeiro $v$ Haberman, [1997] 3 SCR 549 at para 34. 
inconsistent with the separate corporate existence principle, ${ }^{2}$ but is also inconsistent with the interpretation of applicable legislation and the fact that limitation periods are substantive as opposed to procedural.

As it does not appear that Canadian jurisprudence has thoroughly addressed this issue, the American jurisprudence, which is generally consistent with the law in Canada in respect to derivative actions and limitation periods, should be given prominence in articulating the appropriate Canadian approach. Specifically, Canadian courts should adopt the majority test of the "adverse domination doctrine" in calculating the limitation periods for derivate actions. Under this approach, it is the knowledge of the corporation that is relevant for determining limitation periods and, the limitation period would not begin to run in respect to the corporation's claim against the wrongdoers so long as the majority of the board is comprised of wrongdoers or the board is otherwise subject to the control of those wrongdoers. This doctrine is consistent with the identification theory and general agency principles, which hold that a corporation is not imputed with the knowledge of the directors' and officers' own wrongdoing. Rather, it is not until a majority of the board is comprised of non-wrongdoers that the corporation is in a meaningful position to protect its interests and it is at this time that the corporation is imputed the knowledge of such wrongdoing. Accordingly, it is at this time that the limitation period should begin to run.

In respect to the second issue, a review of the case law suggests that Canadian courts have not taken a consistent approach as to what conduct is required to bring the claim within the limitation period. Specifically, Canadian courts have been inconsistent in respect of whether it is the date of filing the leave application or the date of filing the statement of claim that is relevant to satisfying a limitation period. This inconsistent approach is particularly problematic since the two dates are often far enough apart that significantly different results can arise in respect to an argument that a claim is time-barred depending on which date is applied to the analysis. In order to avoid any potential injustices, the filing of the leave application should be considered sufficient in order to ensure that the derivative action is not time-barred.

This article is broken into two parts. In the first part, the theoretical concerns with the application of limitation periods to derivative actions are explained. This part includes a summary of the applicable provisions of the Alberta corporate and limitation legislation and the policy and purpose underlying these provisions. ${ }^{3}$ The Canadian experience in applying limitation periods to derivative actions is also reviewed. A suggested interpretation of the applicable provisions illustrates that it is the corporation's knowledge which is relevant for discoverability purposes. This part also contains a summary of the American jurisprudence in tolling the limitation periods, including the development and application of the adverse

2 Salomon v Salomon \& Co, [1897] AC 22 at 30 (HL (Eng)) where Lord Halsbury stated:

But short of ... proof [of non-compliance with the statute authorizing the creation of the company] it seems to me impossible to dispute that once [a] company is legally incorporated it must be treated like any other independent person with its rights and liabilities appropriate to itself, and that the motives of those who took part in the promotion of the company are absolutely irrelevant in discussing what those rights and liabilities are.

3 The Alberta provisions are used as an example of the existing Canadian principles as the legislation is similar across the country. 
domination doctrine. The section concludes with a discussion of which American approach is most consistent with existing Canadian corporate and limitation principles.

The second part summarizes the practical complications that arise when applying a limitation period to a two-stage process such as a derivative action. Two principles are developed which support suspending or extending the limitation period while the leave application is being considered.

\section{Theoretical Concerns With Limitation Periods AND DERIVATIVE ACTIONS}

\section{A. Applicable Legislation}

\section{CORPORATE LEGISLATION - ROLE OF THE COMPLAINANT AND CORPORATION IN A DERIVATIVE ACTION}

At common law, the case Foss $v$ Harbottle 4 stands for the proposition that for a wrong done to the corporation, only the corporation can sue. ${ }^{5}$ This is a natural consequence of the separate corporate existence principle. This principle has been adopted widely by Canadian courts and continues to serve as a basis to strike actions commenced by a shareholder in his or her personal capacity where the wrong was in fact done to the corporation. ${ }^{6}$ Three concerns motivated this rule: (1) judicial reluctance to get involved with disputes over business policy; (2) a belief that disputes among members of a corporation should be resolved by the members themselves according to the applicable legislation and corporate articles; and (3) a fear of a multiplicity of proceedings. ${ }^{7}$

Over time, equity provided limited exceptions to the rule in Foss, including where the wrong done to the corporation was perpetrated by those who control it. As Lord Denning MR stated in Wallersteiner $v$ Moir (No 2): ${ }^{8}$

\footnotetext{
The rule is easy enough to apply when the company is defrauded by outsiders. The company itself is the only person who can sue.... But suppose it is defrauded by insiders who control its affairs — by directors who hold a majority of shares — who then can sue for damages? Those directors are ... the wrongdoers. If a board meeting is held, they will not authorise ... proceedings to be taken by the company against themselves.... Yet the company is the ... one person who is damnified. It is the one person who should sue. In one way or another some means must be found for the company to sue. Otherwise the law would fail in its purpose. Injustice would be done without redress. ${ }^{9}$
}

These exceptions provided by equity, however, imposed onerous obligations on the shareholders and the right to bring a derivative action could be lost if the acts complained of

(1843), 67 ER 189 (Ch) [Foss].

Ibid at 202-203.

See Hercules Managements Ltd v Ernst \& Young, [1997] 2 SCR 165 at paras 58-62.

See generally Kevin P McGuinness, Canadian Business Corporations Law, 2d ed (Markham, Ont: LexisNexis Canada, 2007) at §13.199.

[1975] 1 QB 373 (CA).

Ibid at 390. 
were ratified. Eventually, the legislatures responded and enacted a flexible procedure and expanded the basis on which a derivative action could be launched. As contemplated in section 240 of the Business Corporations Act (Alberta), ${ }^{10}$ a complainant will be granted leave to "bring an action in the name and on behalf of a corporation" where (1) "the complainant has given notice to the directors of the corporation," (2) "the complainant is acting in good faith," and (3) "it appears to be in the interests of the corporation ... that the action be brought, prosecuted, defended or discontinued." 11

In Richardson Greenshields of Canada Ltd v Kalmacoff, ${ }^{12}$ the Ontario Court of Appeal held that derivative actions serve two purposes. First, they ensure that shareholders have a right to recover property or enforce rights for the corporation if the directors refuse to. Second, they help ensure a degree of accountability over directors who have breached their duties to the corporation. ${ }^{13}$

In granting leave to bring a derivative action, a court must balance two competing policy objectives - "maintaining the integrity of the corporate governance process" and "avoiding undue interference with corporate management that is being conducted in good faith."

Once leave is granted, a review of the evolution of the derivative action shows that while the complainant may be the de facto plaintiff, the corporation is the de jure plaintiff. The fact that a court has power under the $A B C A$ to direct payment to a person other than the corporation does not change the parties' roles. ${ }^{15}$

In the United States, it has been said that the complainant sues as a trustee to redress corporate injuries. ${ }^{16}$ In these situations, the corporations which suffered the injuries are joined as the defendants, rather than the plaintiffs. ${ }^{17}$ In England, at common law, a shareholder brought an action in the shareholder's name on behalf of himself and all other shareholders against the wrongdoing directors and the company. ${ }^{18}$ The shareholder brought this action "in a representative capacity seeking redress for the company." ${ }^{\text {"T }}$ This was abolished with amendments which permitted a shareholder to bring the action in the name of the company itself. $^{20}$

RSA 2000, с B-9 [ABCA].

Ibid, s 240. In Alberta, leave to commence a derivative action can also be granted in an oppression remedy case at s 242(3)(q). (1995), 22 OR (3d) 577 (CA).

Ibid at 584 .

McGuinness, supra note 7 at $§ \S 13.207-13.208$.

While this article focuses on the derivative action, a review of the oppression remedy cases suggests that a derivative action is not required to obtain derivative damages. See e.g. Sparling c Javelin International Ltd, [1986] RJQ 1073 (SC); Malata Group (HK) Ltd v Jung, 2008 ONCA 111.

Discovery Enterprises Inc v Ebco Industries Ltd, [1999] 4 WWR 561 (BCCA) at para 5 [Discovery]. Ibid.

Ibid at para 6.

Discovery Enterprises Inc v Ebco Industries Ltd, 2001 BCSC 235, 86 BCLR (3d) 120 at para 46 [Discovery II].

Discovery, supra note 16 at para 6. 
As noted in Discovery, the authors of the Dickerson Report of 1971 had recommended that Canada follow the English model; however, the authors did not go further to provide any discussion as "to the workings of the derivative action in practice or the role" of the corporation that is being represented by a shareholder "but still being managed by the alleged wrongdoers." ${ }^{21}$ In First Edmonton Place Ltd v 315888 Alberta Ltd, ${ }^{22}$ Justice McDonald quoted the following excerpt from the Dickerson Report which provides some guidance on the role of the complainant:

\begin{abstract}
481. Subsection (1) of s. 19.02 confers upon a complainant the right to apply to a court for consent to bring or intervene in a derivative action in the name and on behalf of the corporation or one of its subsidiaries to enforce a right of the corporation. This provision is largely self-explanatory, but two points merit special emphasis. First, it is most important to keep in mind that this provision relates only to the enforcement of rights of the corporation. It is not available as a remedy to enforce rights of an individual shareholder or even a group of shareholders, although a group of shareholders may bring, in representative form, a derivative action in the name of the corporation if they can characterize the issue as the enforcement of a right of the corporation. Typical examples of cases where a derivative action may be invoked are actions against directors or officers for a breach of duty under s. 9.19 alleging self-dealing or negligence, an action for an injunction to preclude a threatened injury to a corporation, or an action to restrain an act outside the scope of the authority of the corporation, its directors or officers. ${ }^{23}$
\end{abstract}

It is unclear from this statement whether the Dickerson Report authors were referring to a "representative" action as an action where one shareholder represents the interests of other similarly situated shareholders, or whether "representative" action in this context meant that the shareholder was acting in a capacity akin to a litigation representative ${ }^{24}$ for the corporation. The latter is the preferred interpretation and it is consistent with Professor Bruce Welling's commentary in his textbook Corporate Law in Canada: The Governing Principles, ${ }^{25}$ where he explains the capacity in which the complainant pursues the action:

A close analogue is the right of action given to a guardian ad litem to protect the interests of a child in need of protection.... So the shareholder is given ... [the] right of action, representing the corporation, to offset the ordinary principles which would likely result in the corporation's seeming to give up its claim voluntarily.

... the complainant's action consists only of the statutory right to invoke a judge's discretion. A favourable ruling gives the complainant carriage of a different action - a corporate action - in which the complainant will act as a representative on behalf of the corporation. ${ }^{26}$

Ibid at para 7, citing Robert WV Dickerson, John L Howard \& Leon Getz, Proposals for a New Business Corporations Law for Canada, vol 1 (Ottawa: Information Canada, 1971) [Dickerson Report]. (1988), 60 Alta LR (2d) 122 (QB).

Dickerson, Howard \& Getz, supra note 21 at para 481, cited in ibid at 135.

This person is sometimes referred to as a "next friend" or "litigation guardian" or "guardian ad litem" and is the person who undertakes the conduct of the suit on behalf of another party, usually a minor or someone suffering from a mental incapacity. Depending on the jurisdiction, this person may also be liable for cost awards. See e.g. Alberta Rules of Court, Alta Reg 124/2010, r 10.47.

Bruce Welling, Corporate Law in Canada: The Governing Principles, 3d ed (London, Ont: Scribblers Publishing, 2006).

Ibid at 516-17 [footnotes omitted, emphasis in original]. 
In fact, Professor Welling suggests that using the term "derivative action" is a misnomer since the term is based on the development of different common law principles in the US. ${ }^{27}$ Professor Welling suggests that the proper term to refer to the right of a complainant to redress a corporate wrong under Canadian statutes is "statutory representative action," as the right is governed by extraordinary statutory rules. ${ }^{28}$

Further, by analogy to traditional representative actions (situations involving minors and incapacitated persons), most Canadian courts consider that the cause of action belongs to the minor or incapacitated person rather than the litigation representative. ${ }^{29}$ As such, the litigation representative's conduct is rarely considered relevant to the adjudication of the minor or disabled person's claim. ${ }^{30}$

The overwhelming authority suggests that the derivative action belongs to the corporation and as a result, all the substantive rules applicable to the action should be analyzed from the position of the corporation. In the same way that the elements of the causes of action and defences are determined with respect to the plaintiff and defendant, so too should the limitation period be calculated with respect to the plaintiff and defendant. This is consistent with the separate corporate existence principle and the fact that the directors and officers who engaged in the wrongdoing have breached the duties that they owed to the corporation but not necessarily to the complainant.

It appears, however, that the British Columbia Court of Appeal has not characterized the derivative action as being representative. For example, in Discovery the British Columbia Court of Appeal held that the complainant was really the plaintiff and as a result, the complainant did not owe any fiduciary duties to the corporation in conducting the derivative action. $^{31}$ This is not the result you would expect if the complainant was acting in a representative capacity. In Discovery, Discovery Enterprises Inc (Discovery) was a minority shareholder of Ebco Industries Ltd (Ebco) and was seeking leave to commence an action against two directors of Ebco, in the name of and on behalf of Ebco. In considering the role of Discovery in this action, the British Columbia Court of Appeal provided this guidance:

$27 \quad$ Ibid at 526 .

$28 \quad$ Ibid at 527.

29 Re Brick and Manitoba Public Insurance Corp (1983), 144 DLR (3d) 764 (MBCA) at 765 [Brick]; Lucas v Coupal (1930), [1931] 1 DLR 391 (Ont SC) at 391.

$30 \quad$ See e.g. Brick, ibid; Brosseau v Children's Aid Society of the District of Sudbury, Inc (1986), 7 CPC (2d) 312 (Ont SC). But see Millard v Millard (1983) 65 AR 355 (CA) [Millard] where the Alberta Court of Appeal held (at para 6) that minors are bound by the Alberta Rules of Court, supra note 24, and as such, the next friend's failure to address the Notice to Admit facts resulted in the minor's claim being dismissed based on the language of the Limitation of Actions Act, RSA 1970, c 209. In Jespersen v Small (1988), 84 AR 270 (QB), Justice McFadyen did not outright dismiss the minor's claim for his next friend's lack of diligence in pursuing the action. Justice McFadyen ordered that the Public Trustee could pursue the action on behalf of the minor if it took action within 60 days of service of the order. It appears that the serious nature of the minor's injury may have prompted Justice McFadyen to take a more lenient approach than the Alberta Court of Appeal in Millard since it was suggested that the minor had suffered a brain injury and as a result of his disability, might not have capacity to pursue the action when he obtained the age of majority. 
The fact that the company's name is used as plaintiff, presumably to ensure that it receives any damages or other sums ultimately awarded to it, should not obscure the substance of the litigation, which is a contest between the Class D and majority shareholders. Since Discovery has conduct of the action, it will be instructing its counsel as plaintiff's counsel — they will not take instructions from Ebco, and Ebco should not seek advice from them. ${ }^{32}$

This holding is consistent with Justice Maczko's statement in Ginther $v$ Rainbow Management $L t d,{ }^{33}$ where he stated that in the context of derivative actions "a dispute between shareholders and the Companies are merely vehicles though which the parties are carrying out their dispute."34

Two decisions have addressed the implications of the British Columbia Court of Appeal's decision in Discovery. In Northwest Sports Enterprises Ltd v Griffiths, ${ }^{35}$ Justice Smith stated that the holding had to be taken in context. ${ }^{36}$ The issue on appeal in Discovery was whether leave should have been granted; the British Columbia Court of Appeal was not concerned with the carriage of the derivative action itself. ${ }^{37}$ To clarify the roles of the parties to a derivative action and how rights should be analyzed, Justice Smith stated:

The cause of action alleged in the derivative action is one between the company as the injured party and the defaulting directors as the wrongdoers. It is this action that engages equitable principles and if the conduct or the state of mind of the plaintiff is relevant to the material facts comprising the cause of action or to the relief claimed, it is the conduct or state of mind of the company that is in issue, not that of the minority shareholder. $^{38}$

In the second decision, a follow-up to Discovery, Justice Pitfield was faced with a number of issues concerning who could be examined for discovery as a result of the British Columbia Court of Appeal's characterization of Discovery as the plaintiff. Relying on Northwest Sports, Justice Pitfield concluded that while Discovery was the de facto plaintiff, it was not the de jure plaintiff. ${ }^{39}$ Since Ebco was the de jure plaintiff, the discovery rules should be approached as if Ebco was the plaintiff.

In summary, a derivative action is a statutory procedure that was created to overcome the strict rules at common law which stated that only a corporation could sue for harm done to it. A review of commentary and cases suggests that the cause of action advanced through the derivative action belongs to the corporation and the complainant fulfills the role of litigation representative. As such, all substantive rules should be analyzed from the position of the corporation.

\footnotetext{
Ibid at para 9 [emphasis omitted]. 1990 CarswellBC 954 (WL Can) (SC).

Ibid at para 3.

[1999] BCJ no 637 (QL) (SC) [Northwest Sports].

Ibid at para 9.

Ibid.

Ibid at para 11 [emphasis added].

Discovery II, supra note 19 at paras 52-55.
} 


\section{LiMITATIONS LEGISLATION - RULES AND DiSCOVERABILITY}

A plaintiff must bring its claim within the limitation period or the claim will be dismissed for being time-barred. Originally, limitation periods were based on three rationales: (1) at a certain point "a potential defendant should be secure in his [or her] reasonable expectation that he [or she] will not be held to account for ancient obligations"; ${ }^{40}$ (2) claims based on stale evidence should be foreclosed; and (3) plaintiffs should "bring suit in a timely fashion." 41

Traditionally, limitations statutes were oriented towards the interests of potential defendants. ${ }^{42}$ Over time, however, the trend has been to ensure "limitation statutes are framed in a manner that addresses more consistently the plaintiff's interests [and] not just those of the defendant." 43 As a result of this modernization, limitation statues now possess this fourth purpose: to permit a court to "account for the plaintiff's own circumstances, as assessed through a subjective/objective lens, when assessing whether a claim should be barred by the passage of time." 44

While limitation statutes usually require the plaintiff to bring a claim within a specific time period, they also provide a number of exceptions which either suspend or extend the calculation of the time period. For example, all provinces include a provision which states that a limitation period will not run against a plaintiff if he or she is a minor or mentally incapacitated. ${ }^{45}$ Additionally, the Alberta Limitations Act includes a continuing course of conduct provision which states that "a claim, or any number of claims ... resulting from a continuing course of conduct or a series of related acts or omissions, arises when the conduct terminates or the last act or omission occurs." 46 Further, most jurisdictions include a fraudulent concealment provision which suspends the limitation period for the time that the defendant fraudulently conceals the wrongdoing. ${ }^{47}$ Each province also contains some version of a discoverability principle and an ultimate time period in which to bring a claim. The specific time period, the exceptions which suspend or extend the calculation, and the ultimate limitation period reflect the delicate balance between the four purposes or rationales underlying limitation periods.

Section 3(1) of the Limitations Act includes Alberta's discoverability rule as well as its ultimate limitation period. The discoverability rule is the principle the complainant and

\footnotetext{
$M(K) \vee M(H)$, [1992] 3 SCR 6 at 29.

Ibid at 30 .

Novak, supra note 1 at para 64 .

Ibid at para 65.

Ibid at para 67.

See Limitation Acts, 2002, SO 2002, c 24, Sch B, s 7 [ON Limitations Act]; Limitation of Actions Act, RSNS 1989, c 258, ss 4-5 [NS Limitation Act]; The Limitation of Actions Act, CCSM, c L150, s 7 [MB Limitation Act]; The Limitations Act, SS 2004, c L-16.1, s 8 [SK Limitations Act]; Limitation Act, RSBC 1996, с 266, s 7; Limitations Act, RSA 2000, c L-12, ss 5-5.1. Unless otherwise indicated, references to the Limitations Act refer to the Alberta Limitations Act.

See NS Limitation Act, supra note 45, s 29; SK Limitations Act, supra note 45, s 17; MB Limitation Act, supra note 45 , ss 4-5.
}

$46 \quad$ Ibid, s 3(3)(a). 
corporation are most likely to rely on when faced with a limitation issue in a derivative action. Section 3(1) is summarized below:

3(1) Subject to section 11, if a claimant does not seek a remedial order within

(a) 2 years after the date on which the claimant first knew, or in the circumstances ought to have known,

(i) that the injury for which the claimant seeks a remedial order had occurred,

(ii) that the injury was attributable to conduct of the defendant, and

(iii) ... assuming liability on the part of the defendant, warrants bringing a proceeding,

or

(b) 10 years after the claim arose,

whichever period expires first, the defendant, on pleading this Act as a defence, is entitled to immunity from liability in respect of the claim. ${ }^{48}$

The term "claimant" is defined as the "person who seeks a remedial order."49 The term "claim" is defined as the "matter giving rise to a civil proceeding." 50 In Stuffco $v$ Stuffco ${ }^{51}$ Justice Conrad adopted the Alberta Law Reform Institute definition of "claim" as referring to the facts or circumstances giving rise to the alleged right to a remedy. ${ }^{52}$

Judicial interpretation of this provision also reflects the court's movement towards balancing the four purposes or rationales in that it balances the defendant's repose against the plaintiff's unique circumstances. For example, when determining whether a claimant "ought to have known" something, the claimant is required to exercise reasonable diligence to acquire the necessary knowledge. "Although mere suspicion [will] not suffice, the discoverability principle does not require perfect knowledge or certainty."\$3

\section{B. INTERPRETATION OF THE RELEVANT LEGISLATION AND THE CANADIAN EXPERIENCE}

For the purposes of derivative actions, the first main issue that arises when applying the Limitations Act is identifying the claimant. Under the $A B C A$, as discussed above, two parties are involved in pursuing the action - the complainant (the de facto plaintiff, usually a shareholder or creditor) and the corporation (the de jure plaintiff). The calculation of the

Limitations Act, supra note 45, s 3(1).

Ibid, s 1(b).

Ibid, s 1(a).

2006 ABCA 317, 397 AR 111 [Stuffco].

Ibid at paras 25-27.

Borchers v Kulak, 2009 ABQB 457, 479 AR 136 at para 38. 
limitation period could be very different depending on whether the claimant is the complainant or the corporation itself.

If the claimant for the purposes of the Limitations Act is the corporation, then the limitation period would begin to run from when the corporation first knew, or ought to have known, of the wrongdoing attributable to the defendants. This raises a further issue as to the corporation's knowledge. Generally, a corporation can only acquire its knowledge from its directors or officers. ${ }^{54}$ However, as will be discussed in more detail below, there are certain situations where the knowledge of a director or officer will not be attributed or imputed to the corporation.

If the claimant for the purposes of the Limitations Act is the complainant, the limitation period would begin to run from when the complainant first knew, or ought to have known, of the wrongdoing or breach attributable to the defendants. This approach eliminates the additional issues that arise governing the corporation's knowledge of the director's or officer's breach of duty or wrongful conduct. As such, a different limitation period could apply if it is the knowledge of the complainant that is relevant as opposed to that of the corporation. As limitation periods are considered a substantive area of law, as opposed to procedural, ${ }^{55}$ considering the complainant to be the claimant is inconsistent with treating the action as belonging to the corporation. Nonetheless, it appears that the Canadian courts have adopted this latter approach. That is, they have used the knowledge of the complainant for the purposes of determining the limitation period. For instance, in McAteer $v$ Devoncroft Developments Ltd, ${ }^{56}$ Justice Rooke held:

DDL [the corporation] can only bring action through its officers, directors and shareholders. McAteer and Billes certainly are not going to bring action, through DDL, against themselves: Park v. Sunrich Processors Ltd., at para. 26, which cites Drove v. Mansvelt, ... [1998] B.C.J. No. 497 (S.C.), for the proposition that "to expect a director to sanction an action against himself is unrealistic”. That only leaves Mason [the shareholder] to do so, and the evidence that I accept is that she had no knowledge of the Loans, nor could she reasonably have had such knowledge, until after the meeting with Sali on October 9, 1992 (see paras. 18 and 26 of the Statement of Claim in the Mason Action).

Following the Sali meeting Mason would have been in possession of all of the material facts. Accordingly, the limitation period would have begun to run on or shortly after October 9th, 1992, expiring on or shortly after October 9, 1998. Thus, as Mason would have had, or been able to discover, the knowledge of the Officer's Certificates and the \$200,000 Loan from DDL on or before November 23, 1992, and the Derivative Action was deemed to have been commenced as of November 24, 1998, I find that these claims are outside the limitation date and, as such, are dismissed. ${ }^{57}$ Denning compares a corporation to the human body and draws analogies between the different functions performed by the body and the different roles performed by directors and other employees. This passage is frequently cited as a basis for the identification doctrine which will be discussed in greater detail in Part II.D.

55 See Tolofson $v$ Jensen, [1994] 3 SCR 1022.

56 2001 ABQB 917, 307 AR 1 [McAteer].

57 Ibid at paras 724-25 [emphasis added]. 
This holding does not acknowledge the separate corporate existence principle. Even though Pamela Mason filed the statement of claim seeking a remedial order, the right to such remedial order belonged to Devoncroft Developments Ltd (DDL). Given the guidance in Northwest Sports, the limitation period should have been calculated from the date when DDL discovered all the elements of the action. However, in fairness to the Court in McAteer, the derivative action was not really argued, ${ }^{58}$ and as such, it is understandable that the Court did not address specifically who was the claimant for the purposes of the Limitations Act.

Carr $v$ Cheng ${ }^{59}$ is another example where the trial judge calculated the limitation period for the purposes of a derivative action from the point when the complainant knew of all the elements of the action. Again, since the decision focused on the oppression remedy, it does not appear that Justice Rice was presented with an argument that the calculation of the limitation period should have been made with respect to when the corporation discovered all the elements of the action.

Park $v$ Sunrich Processors $L t d^{60}$ is a further example. In this case, the wrongdoing was committed in 1989 and, under the six-year limitation period, the action was time-barred in 1995. The complainant did not become aware of the wrongdoing until 1991. The petition was filed in 1997. The complainant argued that under the discoverability principle, the limitation period was postponed until he became aware of the wrongdoing. Justice Holmes granted the complainant leave to commence a derivative action.

The calculation of the limitation period in these cases may be explained by the fact that many derivative actions are also tried at the same time as oppression actions and there appears to be confusion in the case law as to whether certain claims must be addressed by way of derivative action or by way of oppression remedy. This is mainly due to the wording of the applicable legislation which suggests that derivative relief can be recovered in an oppression action, and shareholders can recover personal damages in a derivative action. In many situations, the same wrongdoing will often result in harm to both the corporation and the complainant. It must be remembered, however, that the two actions are distinct and reflect the rights of different plaintiffs.

In summary, the Canadian jurisprudence suggests that the limitation period for derivative actions is calculated from the time that the complainant, rather than the corporation, knew all the elements of the action.

I must say at the outset that the Derivative Action, prosecuted by Mason on behalf of DDL, was not prosecuted very actively in the evidence or argument. I believe this is so because it was realized that no useful benefit would be obtained by DDL and Mason's recovery could be as easily, or more easily, accomplished under the oppression remedy. I agree with this rationale and that result has turned out to be the case. Accordingly, I will be quite brief in my findings and reasons in this section. 


\section{AMERICAN AUTHORITIES - THE DEVELOPMENT AND Application Of THE AdVERSE Domination Doctrine}

\section{HistoricAl DEVELOPMENT OF TOLLING PRINCIPLES}

The American jurisprudence on limitation periods has followed a similar path as the Canadian jurisprudence and is based on similar underlying rationales. ${ }^{61}$ The courts were originally faced with specific time periods in which plaintiffs had to bring their claims. ${ }^{62}$ Over time, finding that these specific limitation periods provided unfair results, the US courts relied on the equitable principle of laches and developed a number of principles to "toll" the running of the limitation statutes. ${ }^{63}$ Such tolling principles included fraudulent concealment and the discovery rule, ${ }^{64}$ which are similar in principle to their Canadian counterparts.

However, unlike in Canada, the US courts specifically developed two tolling principles to address limitation periods as they applied to a corporation's claim. The first principle was developed by the Court of Chancery of Delaware in Kahn v Seaboard Corp ${ }^{65}$ and applies specifically to derivative actions. In Kahn, a derivative action was brought on behalf of Seaboard Corporation against the controlling shareholder and three of the corporation's directors. It was alleged that the individual defendants caused the corporation to engage in numerous transactions with a related entity to the corporation's detriment. These transactions were entered into in 1986 and the action was commenced in 1990. The applicable limitation period was three years. The issue the Court of Chancery of Delaware had to address was whether the statute of limitations could be tolled to bring the derivative action within the limitation period.

The Court of Chancery of Delaware noted that the relationship of trust and reliance between shareholder and management is such that the statute of limitations should not be applied "woodenly or automatically to alleged self-interested violations of trust." 66 The Court held that the statute of limitations may be tolled in instances that extend beyond fraudulent concealment and specifically noted that "the statute of limitations applies, but is tolled in derivative actions charging actionable self-dealing, until the shareholders knew or had reason to know of the facts constituting the alleged wrong." 67 This principle is consistent with the Canadian approach where it is the knowledge of the complainant that is given prominence in the limitation period calculation. This approach raises the same difficulties as the Canadian approach, in that the calculation of the limitation period may be different even though the limitation period is a substantive rule of law and its calculation should be the same regardless of who in fact brings the action.

61

Michael E Baughman, "Defining the Boundaries of the Adverse Domination Doctrine: Is There Any Repose for Corporate Directors?” (1995) 143:4 U Pa L Rev 1065 at 1069: “Statutes of limitations generally are perceived as having two purposes: a 'substantive' purpose in granting repose to defendants and a 'procedural' purpose in encouraging plaintiffs to bring suit in a timely manner.”

Ibid.

Ibid at 1072 .

Ibid at $1073-77$.

625 A (2d) 269 (Del Ch 1993) [Kahn].

Ibid at 275.

Ibid at 276 [emphasis added]. 
The second line of authority deals with the doctrine of adverse domination. ${ }^{68}$ The principle of adverse domination was summarized in Clark v Milam: ${ }^{69}$ "Adverse domination is an equitable doctrine that tolls statutes of limitations for claims by corporations against its officers, directors, lawyers, and accountants for so long as the corporation is controlled by those acting against its interests." 70

The adverse domination principle arose in response to the savings and loan crisis of the 1980s and 1990s. ${ }^{71}$ The Federal Deposit Insurance Corporation (FDIC) pursued claims against directors and officers on behalf of failed banking institutions as a result of the directors' and officers' improvident lending practices. ${ }^{72}$ Under the limitation rules that existed at that time, almost all of these claims were statute-barred. In the pivotal case of FDIC $v$ Bird, ${ }^{73}$ the FDIC cited a handful of older cases that recognized a "domination and control" tolling exception where the bank's cause of action would not accrue "while the culpable directors remain[ed] in control of the bank."”74

With the success in the savings and loan cases, the courts expanded the application of the adverse domination doctrine to other corporate litigation situations, including bankruptcy cases and shareholder derivative actions. ${ }^{75}$ By the early 1990s, limitation periods were not measured from the date of the director's or officer's breach of duty but were rather measured from the time that the corporation was in a meaningful position to police that misconduct. ${ }^{76}$

These early cases provided the following reasons which supported the adoption and application of the adverse domination doctrine: as a practical matter, while the wrongdoers control the corporation, the corporation is unlikely to sue them; such wrongdoers "have a duty to disclose or police their own misconduct, which they [then] breach by failing to take action against themselves"; ${ }^{77}$ and such wrongdoers are the only means for the corporation to acquire notice of the corporation's claims against them. ${ }^{78}$

A number of rationales have been advanced to support adopting the adverse domination doctrine. ${ }^{79}$ The first suggests that a corporation is under a decisional disability during the period that the wrongdoers are in control of the corporation. ${ }^{80}$ Just as the limitation period

It appears as though numerous federal courts as well as the state courts of Kansas, Pennsylvania, Illinois, Kentucky, Maryland, West Virginia, and Massachusetts have adopted some form of the adverse domination doctrine. States courts which have considered and declined to adopt the adverse domination doctrine include Delaware, Arkansas, Georgia, and Virginia. 452 SE (2d) 714 (W Va Sup Ct App 1994) [Clark]. Ibid at 718 .

Matthew G Doré, "Statutes of Limitation and Corporate Fiduciary Claims: A Search for Middle Ground on the Rules/Standards Continuum” (1997) 63:3 Brook L Rev 695 at 706.

Ibid at 710 .

516 F Supp 647 (DPR 1981).

Ibid at 651 .

Doré, supra note 71 at 713-14.

Ibid at 714-15.

Ibid at 736-37.

Ibid.

See Doré, ibid at 762 (it is said that these separate rationales are all rooted to varying degrees in corporate fiduciary duty analysis).

Ibid at 741-43. 
does not run against an individual while he or she is disabled, the same should be said of corporations.

The second rationale relates to the power of the wrongdoers to conceal incriminating evidence. ${ }^{81}$ Concealment in this instance is not referring to fraudulent concealment; it relates to the wrongdoers factual control over the information. ${ }^{82}$

The third rationale is the discovery rule, and suggests that so long as wrongdoers "remain in control of a corporate entity, the corporation has no 'notice' of [the] claims that implicate them." ${ }^{83}$ As such, a corporation is "blamelessly ignorant" of the claims that implicate the wrongdoers, at least while they control the corporation. ${ }^{84}$ It is said that the adverse domination doctrine "is akin to the discovery rule because [the] adverse domination [doctrine] is also based on the principle of 'inherently unknowable harm., "»85

Under the US discovery rule, the courts apply agency law to determine when a corporation discovers or has notice of a litigation claim. The "imputed notice" rule states that a principal is bound by the knowledge of its agents except in "situations where the agent's interests are 'adverse' to the principal." ${ }^{\text {" A6 }}$ As such, the knowledge of a majority of directors of their own wrongdoing is not imputed to the corporation, as this inherent conflict of interest makes the directors adverse to the corporation with respect to the claim. ${ }^{87}$

\section{IsSUES AND APpliCATION OF THE ADVERSE DOMINATION DOCTRINE}

Initially, the only issue that divided courts was the required level of domination. One line of authority held that so long as the majority of the board was comprised of wrongdoers, the limitation period would be tolled. ${ }^{88}$ This is referred to as the majority test or the "majority disinterested director" test. ${ }^{89}$ A majority of jurisdictions in the US apply the majority test. ${ }^{90}$ This version of the adverse domination doctrine would require a change of control of a board of directors from a majority of wrongdoers to a majority of non-culpable directors before notice of the claim would be imputed to the corporation. ${ }^{91}$

An alternate line of cases has held that adverse domination requires the wrongdoers to have "full, complete and exclusive control" of the board of directors. ${ }^{92}$ This is referred to as the "complete domination" test ${ }^{93}$ or the "single disinterested director" test. ${ }^{94}$ Under this latter

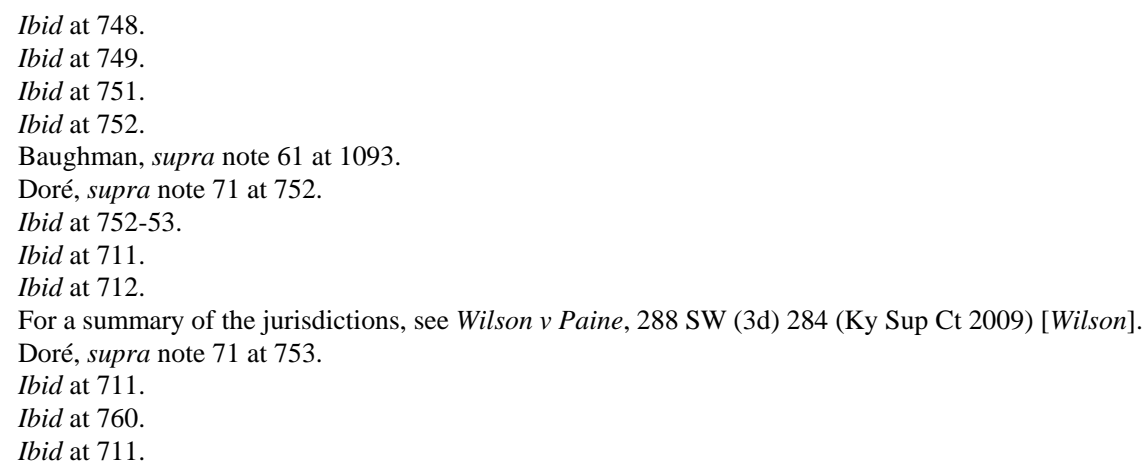


approach, the presence of a single disinterested director on the board of directors would be sufficient to start the limitation period since notice of claim to this disinterested director would be imputed to the corporation. ${ }^{95}$ However, the effectiveness of this approach is questionable in instances where this single disinterested director is unwilling to pursue an otherwise valid claim against the other directors, or does not inform the shareholders about the wrongdoing. In such a circumstance this disinterested director would also become culpable for aiding or abetting the wrongdoing and as a result, the wrongdoers would completely control the board of directors.

In Hecht $v$ Resolution Trust Corp,$^{96}$ the Maryland Court of Appeal went so far as to state that both versions of the adverse domination doctrine operated as rebuttable presumptions. For example, under the majority test, until an independent majority takes control of the board, the corporation is entitled to a presumption that it cannot discover its cause of action. ${ }^{97}$ This presumption can be rebutted where the defendants show that there was someone who had the knowledge, ability, and motivation to bring the claim during the period in which the defendants controlled the corporation. ${ }^{98}$ The Maryland Court of Appeal felt that it is appropriate that the wrongdoers bear the burden as "they have greater access to relevant information."99

Over time, different issues have arisen in the doctrine's application, which has resulted in judicial restraint. Specifically, US courts are currently divided as to whether the adverse domination doctrine applies to toll claims based in negligence, or whether the directors and officers must be guilty of "some sort of self-dealing or fraudulent conduct" before the doctrine can be used to toll the limitation period. ${ }^{100}$

For example, in FDIC v Dawson, ${ }^{101}$ the Court summarized its concern with giving the adverse domination doctrine too broad a reach:

To [allow a negligence standard] would effectively eliminate the statute of limitations in all cases involving a corporation's claims against its own directors.... [I]t could almost always be said that when one or two directors actively injure the corporation, or profit at the corporation's expense, the remaining directors are at least negligent for failing to exercise "every precaution or investigation.”... If adverse domination theory is not to overthrow the statute of limitations completely in the corporate context, it must be limited to those cases in which the culpable directors have been active participants in wrongdoing or fraud, rather than simply negligent. ${ }^{102}$

Ibid at 754; see Clark, supra note 69 (to permit the tolling in these situations, some US courts have permitted the plaintiff to show that the disinterested director would not have been willing or able to sue in any event).

635 A (2d) 394 (Md Ct App 1994) [Hecht]. The presumption was also applied by the Supreme Court of Kentucky in Wilson, supra note 90.

Hecht, ibid at 406.

Ibid.

Ibid at 408.

Doré, supra note 71 at 716.

4 F (3d) 1303 (5th Cir 1993).

Ibid at 1312. 
The different rationales for the adverse domination doctrine may help reconcile the converging opinions on these issues. For example, if a court adopts the decisional disability rationale, then it will also likely adopt the majority test and hold that the adverse domination doctrine is applicable to all types of claims. This is because the corporation's decision to bring litigation typically rests with the majority of the board of directors, and under the "duty of loyalty principles, where directors act subject to a conflict of interest ... their decision should not bind the corporation." 103 Thus, practically speaking, the "disability" exists until an independent majority on the board of directors is elected. Additionally, the type of claim against the director should make no difference since "a corporation is no less 'disabled' by [a] directors' conflict of interest and power of control with respect to negligence claims than it is with respect to" fraud claims. ${ }^{104}$ Whether the claim is framed as negligence or fraud, the directors may not wish to expose the matter to litigation. In principle, the adverse domination doctrine should apply in all such situations.

\section{Practical Concerns of Applying the Adverse Domination DOCTRINE TO DERIVATIVE ACTIONS}

Academic commentary also suggests that judicial restraint reflects the courts' concern with striking the appropriate balance between the specific limitation periods (referred to as the rules approach) and the flexibility required to address a plaintiff's unfortunate situation (referred to as standards approach). ${ }^{105}$ Bright line rules provide better guidance to the judiciary and result in resolution with fewer errors at a lower cost. ${ }^{106}$ Bright line rules, however, "will bar some claims where [the] plaintiff's delay in filing suit is reasonable and [the] defendant is not prejudiced." ${ }^{\text {"107 }}$ The standards approach, in contrast, attempts to provide more equitable results. ${ }^{108}$

As a practical matter, the adverse domination doctrine is fact intensive, and as such, decisions relating to tolling the limitation period under adverse domination are rarely determined before trial. ${ }^{109}$ Thus, it is inconsistent with the principles underlying limitation periods in that the rule does not provide repose or bar litigation of stale claims in any meaningful way. ${ }^{110}$

The adverse domination doctrine may also permit the litigation of claims that fall outside the terms of corporate insurance policies which require that the claims be "based on conduct that occurred within a defined time window."111 This raises additional concerns for the corporation and its board of directors.

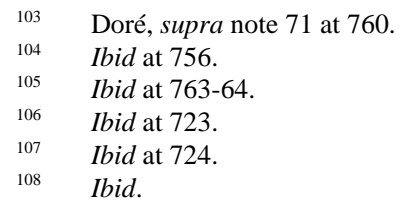

109 See e.g. Doré, ibid at 765, where he suggests that the following information is relevant: the allegations of wrongdoing; "the makeup of the board of directors and its various members' level of 'disinterest' with respect to the ... allegations" and "the ability of the 'interested' board members to exert control over the corporation.” 
The United States District Court for the District of Delaware in Re Marvel Entertainment Group $^{112}$ recognized another practical concern about the adverse domination doctrine. In Marvel, the directors caused the corporation to enter into a tax sharing agreement with the majority shareholder. This agreement was disclosed to all shareholders and the public through the annual reporting requirements. A number of years later when there was a change of control of the board of directors, the shareholders brought a derivative action alleging that the former directors breached their duties to the corporation by entering into this tax sharing agreement, as the majority shareholder benefited at the expense of the corporation.

In assessing the applicability of the adverse domination doctrine, the District Court of Delaware focused on the ability of shareholders to bring a derivative action on behalf of a corporation. In fact, the Court noted that in Clark, the Court of Chancery of Delaware held that the adverse domination doctrine does not apply once the shareholders learn about the misconduct. ${ }^{113}$ Specifically, the District Court of Delaware noted that

when disclosures of the alleged harmful acts are made to shareholders, the corporate entity is no longer without redress against those who control it because the shareholders have both the knowledge and authority to protect the corporation's rights, and that therefore, there is no reason to toll the statute of limitations. ${ }^{114}$

Indeed, the District Court of Delaware did not adopt the adverse domination doctrine and noted the following:

Because the court believes that Delaware's [equitable] tolling mechanisms, in combination with the availability of shareholder derivative actions, already address the concerns that underlie the adverse domination doctrine, the court declines to recognize adverse domination as a viable tolling mechanism in Delaware. $^{115}$

Academic commentary suggests that shareholder notice may be a sufficient alternative in calculating limitation periods in derivative actions since it achieves the same goals as the adverse domination doctrine; it determines the point at which a corporation is able to pursue litigation against the directors and officers who have engaged in wrongdoing against the corporation. ${ }^{116}$ It also avoids all of the difficulties with determining the corporation's knowledge and the debate between the majority test and the complete control test. ${ }^{117}$ Additionally, limitation issues based on shareholder knowledge can be readily resolved before trial "since the information that controls the outcome ... will by definition be that which the corporation has already made available." 
Other US cases have held that the shareholder's knowledge is irrelevant to determining the limitation period for a corporation's action against the wrongdoers. ${ }^{119}$ This is based on a number of well-established corporate law principles. For example, a shareholder of a corporation is not an agent of the corporation and his or her knowledge is not imputed to the corporation. ${ }^{120}$ Additionally, a shareholder has no power to act for or bind the corporation. ${ }^{121}$ Lastly, a shareholder has no duty to protect the corporation or to institute a derivative action on behalf of a corporation. ${ }^{122}$ In fact, the derivative action procedure, requiring good faith and notice to the directors, "is designed to prevent [a shareholder] from interfering with legitimate discretion in corporate governance."

Some US legal practitioners suggest that a shareholder who brings a derivative action to assert a cause of action for the corporation is asserting that claim in "the same representative capacity as a guardian or parent who brings an action as 'next friend' on behalf of a minor" or person under a mental disability. ${ }^{124}$ In these cases, the American jurisprudence consistently adopts the view that the knowledge or lack of diligence by the "next friend" does not affect the tolling of limitation periods for the minor or disabled person. ${ }^{125}$

In summary, a majority of US courts recognize the adverse domination doctrine and use the knowledge of the corporation for calculating the limitation period for the corporation's claim against its directors or officers for their wrongdoings. Further, a majority of these courts apply the majority test in that a corporation is said to discover all the elements of the cause of action when independent directors are in control of the board. When this occurs, the corporation is in a meaningful position to protect its interests. The courts are still divided as to whether the adverse domination doctrine should apply to negligence claims or just fraud and self-dealing. If fraud or self-dealing is required, then there is no practical difference between the adverse domination doctrine and the fraudulent concealment doctrine. As such, to provide any meaningful expansion to the common law, the adverse domination doctrine must apply to negligence.

See Allen v Wilkerson, 396 SW (2d) 493 at 502 (Tex Ct Civ App 1965): "And where, as here, the management of a corporation's affairs are de facto under the domination and control of the adversary of such cause of action, or the corporation is de facto powerless to sue on such cause of action because of the lack of a disinterested majority of its board, mere notice to shareholders does not start running of limitations against the corporate cause of action." See also Resolution Trust Corp v Fleischer, $890 \mathrm{~F}$ Supp 972 (Kan Dist Ct1995) at 978 [Fleischer]: "Generally, the knowledge of a particular shareholder or shareholders is not material in considering the statute of limitations as a bar to a claim of the corporation itself." See also Liken v Shaffer, 64 F Supp 432 at 442 (ND Iowa Dist Ct 1946): "The knowledge or lack of knowledge of an individual stockholder not connected with a corporation other than as a stockholder is not material in considering the statute of limitations as a bar to the claim of the corporation itself." See also Whitten v Dabney, 171 Cal 621 at 629 (Cal Sup Ct 1915): "So long as the corporation itself remains ... in the hands of a board of directors accused of participation in the frauds, the statute of limitations does not run against it."

Fleischer, ibid at 977.

See Accent Energy Corp v Gillman, 824 SW (2d) 274 at 278 (Tex Ct App 1992).

Fleischer, supra note 119 at 978.

Eye Site, Inc v Blackburn, 796 SW (2d) 160 at 161.

Fryar Law Firm PC, "Limitation Issues in Shareholder Derivative and Oppression Suits," online: Fryar Law Firm <http://www.fryarlawfirm.com/Shareholder/Texas/Limitations.html>.

Ibid. 
The Delaware approach, which is consistent with the existing Canadian approach, fails to recognize the separate corporate existence principle and the fact that the derivative action is used to pursue the corporation's action against the directors and officers. It is also inconsistent with the well-established corporate law principle that the shareholder's knowledge is not imputed to the corporation and a shareholder is under no duty to pursue a derivative action. As such, the shareholder's knowledge of the wrongful conduct should be considered irrelevant in determining the appropriate limitation period in a derivative action.

\section{Proposed Canadian Approach}

The majority test of the adverse domination doctrine is consistent with the principles and rationales underlying Canadian corporate and limitation legislation, as discussed above. This approach recognizes the separate corporate existence principle and provides a balanced approach to recognizing the four purposes or rationales underlying limitation periods, in that it balances the defendant's right to repose against the plaintiff's unique circumstances. Additionally, as all provincial jurisdictions have recognized some form of discoverability, the adverse domination doctrine is a logical extension of the discoverability principle.

The adverse domination principle is consistent with the Canadian principles that govern when a director's or officer's knowledge of his or her own wrongful conduct is attributed to the corporation and the well-established principles governing the relationship between shareholders and corporations. If adopted in Canada, the majority test of the adverse domination doctrine should apply to negligence as well as fraud. Often the distinction between fraud, equitable breach of fiduciary duty, and negligence is a fine line to draw. For the purposes of calculating a limitation period in a derivative action, there is no principled reason to treat the causes of action differently.

\section{KNOWLEDGE OF THE CORPORATION}

Although a corporation is legally considered a person, it can only act through the conduct of others. It is only through its employees, agents, and directors that a corporation can enter into contracts and own property. A corporation can also commit crimes and regulatory offences, as well as intentional torts and negligence, which are also committed through the conduct of others. In order to hold a corporation liable primarily for a mens rea criminal offence or an intentional tort, ${ }^{126}$ the act and mental elements of the offence or cause of action must still be made out. This poses a problem in differentiating between the acts and thoughts of the individual employee, agent, or director and those of the corporation. Cases have considered this practical stumbling block in identifying the corporate mens rea or the corporation's “thinking mechanism that did the intending."

Under the identification theory, a corporation will be found to have the requisite mens rea and actus reus "so long as the employee or agent in question is [in] such a position [within] the organization and activity of the corporation that he or she represents its de facto directing

126 As opposed to holding the corporation liable for a strict liability offence or vicariously liable for the torts committed by its employees, agents, or directors. 
mind"128 so that the corporation is identified with the act and mind of that individual. Subsequent cases have held that the directing mind is the person or persons responsible for policy-making functions as opposed to those responsible for purely operational functions. ${ }^{129}$ In these cases, one could say that the directing mind's conduct and mental state is attributed or imputed to the corporation. The Supreme Court of Canada recognized, however, that an exception must be made where the directing mind is committing a wrong against the corporation itself. As Justice Estey stated:

Where the criminal act is totally in fraud of the corporate employer and where the act is intended to and does result in benefit exclusively to the employee-manager, the employee-directing-mind, from the outset of the design and execution of the criminal plan, ceases to be a directing mind of the corporation and consequently his acts [cannot] be attributed to the corporation under the identification doctrine.... [I]n my view the identification doctrine only operates where the Crown demonstrates that the action taken by the directing mind (a) was within the field of operation assigned to him; (b) was not totally in fraud of the corporation; and (c) was by design or result partly for the benefit of the company. ${ }^{130}$

While this statement relates to a directing mind's wrongful acts, it is equally relevant to the directing mind's knowledge of those wrongful acts. As a result, in derivative actions, a directing mind's knowledge of wrongdoing committed against the corporation by himself or herself should not be attributed to the corporation where the wrongdoing is a complete fraud on the corporation. As such, the limitation period should not begin to run the moment the fraud is committed. Were it otherwise, the calculation of the limitation period under the discoverability principle for wrongs committed by a directing mind would unjustly favour the defendant. In $R v$ Rozeik, ${ }^{131}$ Lord Justice Leggatt provided the following rationale on why a directing mind's knowledge cannot be attributed to the corporation in these situations:

It is not a question of the manager having notice of the fraud: his state of mind is the state of mind of the company, and the company is deceived unless the manager is party to the deception. The reason why the company is not visited with the manager's knowledge is that the same individual cannot both be [a] party to the deception and represent the company for the purpose of its being deceived. ${ }^{132}$

The identification theory is difficult to apply as modern corporations often no longer follow a pyramid model where it is easy to identify the directing mind. Many corporations are international conglomerates with multiple divisions and multiple layers of decisionmaking. Additionally, the theory fails to hold a corporation accountable when employees or agents in operational roles are responsible for serious misconduct.

The identification doctrine is also consistent with the circumstances where the law will refuse to attribute knowledge to the principal in agency situations. Generally, the knowledge

Canadian Dredge \& Dock Co v R, [1985] 1 SCR 662 at 675 [Canadian Dredge] [emphasis in original]. See e.g. Rhône (The) v Peter AB Widener (The), [1993] 1 SCR 497 at 526, where Justice Iacobucci stated that" $[t]$ he key factor which distinguishes directing minds from normal employees is the capacity to exercise decision-making authority on matters of corporate policy, rather than merely to give effect to such policy on an operational basis.”

Canadian Dredge, supra note 128 at 713-14.

[1996] 3 All ER 281 (CA).

Ibid at 286. 
of the agent will be attributed to the principal where the agent's knowledge was acquired while acting within the scope of the agent's actual or apparent authority; the knowledge is relevant to the transaction in which the agent is employed; and the agent is under a duty to communicate the knowledge to the principal. ${ }^{133}$ Knowledge will not be attributed to the principal, however, where the agent is engaged in a fraud or misfeasance against the interests of the principal. ${ }^{134}$

\section{RELATIONSHIP BETWEEN SHAREHOLDERS AND CORPORATIONS}

Corporate legislation outlines what corporate powers can be exercised by the directors and which can be exercised by the shareholders. This division of power prevails in the absence of a unanimous shareholders agreement. Under such legislation, shareholders are entitled to elect and remove directors, ${ }^{135}$ can attend annual meetings, and review the corporation's financial information. ${ }^{136}$ They do not, however, gain any proprietary rights in the corporation by virtue of being a shareholder. ${ }^{137}$ The corporation owns its assets and in general, the shareholders have no right to call for the property of the corporation. ${ }^{138}$ Additionally, the share itself consists of a bundle of rights which include, subject to the articles, the right to a dividend, the right to a portion of the assets upon winding up, and the right to vote. ${ }^{139}$

The majority of corporate power, including the power of managing and carrying on the corporation's business, is vested in the directors. ${ }^{140}$ The directors' power to manage the corporation is complete until the director is removed from office and is not fettered by the shareholders. ${ }^{141}$ As a result, shareholders have no general power to bind the corporation through a general meeting. ${ }^{142}$ Similarly, shareholders are not agents of the corporation and cannot bind the corporation through agency principles. ${ }^{143}$ Further, shareholders do not owe the corporation any fiduciary duties and are not obligated to account for profits made at the expense of the corporation or its other shareholders. ${ }^{144}$ Comparable to the American jurisprudence, these principles suggest that the shareholder's knowledge is similarly irrelevant in Canadian law for the purposes of calculating the corporation's limitation period.

The relationship between the oppression remedy and the derivative action is also helpful to explain the relevance of shareholder knowledge. A shareholder's knowledge of wrongdoing would be relevant to the shareholder's oppression action and would act as a bar

See generally Gerald Fridman, Canadian Agency Law, (Markham, Ont: LexisNexis Canada, 2009) at $\S \S 10.7-10.9$.

Ibid.

See e.g. ABCA, supra note 10, ss 106, 109; Ontario Business Corporations Act, RSO 1990, c B.16, ss 119, 122 [OBCA]; Canada Business Corporations Act, RSC 1985, c C-44, ss 106, 109 [CBCA].

See e.g. ABCA, ibid, Parts 11, 13; OBCA, ibid, Part VII; CBCA, ibid, Parts XII, XIV.

Teck Corp Ltd v Millar (1972), 33 DLR (3d) 288 at 307 (BCSC) [Teck].

United Fuel Investments Ltd v Union Gas Company of Canada Ltd, [1966] 1 OR 165 (CA).

Bradbury v English Sewing Cotton Co Ltd, [1923] AC 744 at 753 (HL (Eng)).

See e.g. ABCA, supra note 10, s 101; OBCA, supra note 135, s 115; CBCA, supra note 135, s 102.

Teck, supra, note 131 at 307.

McGuinness, supra, note 7 at § 2.13; see Grundt v Great Boulder Proprietary Mines Ltd, [1948] Ch 145 at 157 (CA).

McGuinness, ibid, § 2.122.

See William B Sweet \& Associates Ltd v Copper Beach Estates Ltd (1993), 108 DLR (4th) 85 (BCCA); McGuinness, supra note 7 at 1170, n 401. 
to relief if the shareholder failed to commence the oppression action within the requisite period of time. However, a shareholder's knowledge of the wrongdoing should not bar a derivative action on behalf of the corporation since unlike the oppression remedy, the plaintiff would be the corporation. One concern that arises with this approach is the possibility that the shareholder will use the derivative action to obtain a personal remedy when the limitation period under the oppression remedy expires.

A shareholder should not be permitted to do something indirectly that it cannot do directly. It is suggested that if a shareholder failed to commence an oppression action within the limitation period and then commenced a derivative action seeking a personal remedy, the courts should exercise their discretion and deny any personal remedy claimed by the shareholder. Thus, the only relief available under the derivative action in these situations should be relief directed towards the corporation. This is a fair result and reflects the distinction between the different rights protected by the two actions.

In summary, the majority test of the adverse domination doctrine is consistent with the identification theory, Canadian agency principles, and Canadian corporate principles governing the relationship between shareholders and corporations.

\section{Practical Concerns within Limitations Periods AND DERIVATIVE ACTIONS}

\section{A. Bringing the Derivative ACtion within the Limitation Period}

Based on the discoverability rule in section 3 of the Limitations Act, in order for a claim to proceed and not be dismissed as time-barred, the claimant must seek a remedial order within two years from the date the claimant knew or ought to have known all the elements of the action. ${ }^{145}$ The majority of this article has focused on when the limitation period commences under the discoverability rule and the complications that arise when a court has to determine the knowledge of a corporation controlled by wrongdoers. This part addresses the practical difficulties in applying the limitation period to a two-stage process, and the conflicting interpretations of what it means to "seek a remedial order." For the purpose of this section, and for simplicity, the date that the claimant knew or ought to have known all the elements of the action will be referred to as the "Discoverability Date."

In a derivative action commenced under the $A B C A$, a complainant must seek leave of the court before it can file the corporation's claim against the wrongdoers. However, as discussed above, to bring the derivative action within the limitation period the claimant must seek a remedial order within two years from the Discoverability Date. The issue created by this two-stage process is whether applying for leave to issue a statement of claim is akin to seeking a remedial order or whether the statement of claim must be filed within the two-year period to prevent the claim from being time-barred. Depending on the approach, a further problem is created when a leave application is delayed or appealed. 


\section{GENERAL PRINCIPLES}

The filing of a statement of claim is widely recognized as being the conduct required to bring the action within the limitation period. ${ }^{146}$ That is, under the discoverability rule, if the statement of claim is not filed within two years from the Discoverability Date, the claim is time-barred and the defendant is entitled to immunity from liability. Where an action is commenced by originating notice, the originating notice must be filed within two years from the Discoverability Date as well. ${ }^{147}$ Thus, the courts treat the two routes the same for limitation purposes. The results are the same in other provincial jurisdictions. In Kemp $v$ Metzner $^{148}$ the British Columbia Court of Appeal considered its provincial limitation legislation and held that to "bring an action" was synonymous with the initiation of the legal proceedings, or in that case, the issuance of the writ. ${ }^{149}$

The courts consider the filing of the statement of claim or originating notice as the conduct required to bring an action within the limitation period since the filing of the statement of claim or originating notice commences the proceedings or action under the Alberta Rules of Court. ${ }^{150}$ In other words, courts simply assume that to "seek a remedial order" is synonymous with starting an action or commencing proceedings. ${ }^{151}$

The leave requirement is not unique to derivative actions and how leave is treated in general is instructive to how leave should be treated in derivative actions. In cases where many procedural steps are required before the statement of claim is filed, including applying for leave or giving notice of the claim, the courts have generally concluded that the first step in this multi-stage process is sufficient to bring the action within the limitation period. ${ }^{152}$ However, as discussed below, these general principles have not been applied to derivative actions.

See Garry v Canada (Minister of Justice), 2007 ABCA 234, 429 AR 292 at paras 19-20; Northey-Taylor $v$ Casey, 2008 ABCA 149, 429 AR 302 at paras 5, 19-24; Stuffco, supra note 51 at para 46; Gratton v Shaw, 2011 ABCA 175, [2011] AJ no 636 (QL) as examples of situations where the courts treat the issuing or filing of the statement of claim as seeking a remedial order. See Yugraneft Corp v Rexx Management Corp, 2007 ABQB 450, 423 AR 241 at paras 20, 72, aff'd 2008 ABCA 274, 433 AR 372, aff'd 2010 SCC 19, [2010] 1 SCR 649 [Yugraneft]. 2000 BCCA 462, 190 DLR (4th) 388.

Ibid at paras 27-30.

Alta Reg 124/2010, s 3.2 .

See Yugraneft, supra note 147 at para 42, where Justice Chrumka stated, "The general rule pursuant to the Limitations Act is that an action must be commenced within two years of the knowledge of the cause of action." In other jurisdictions, the legislation explicitly includes the phrase "commence proceedings." For example, SK Limitations Act, supra note 45, s 5 states that "no proceedings shall be commenced with respect to a claim after two years from the day on which the claim is discovered." Similarly, ON Limitations Act, supra note 45, s 4 states "a proceeding shall not be commenced in respect of a claim after the second anniversary of the day on which the claim was discovered."

152 See also Doel v Kerr (1915), 25 DLR 577 (ONSC (AD)) where under the existing limitation period a plaintiff was prohibited from bringing an action after the lapse of the prescribed period. The term "action" was defined as including "any civil proceeding." The appellate division of the Ontario Supreme Court held that an application for leave to issue execution was such a proceeding. But compare this holding to Stubbs v Allen, [1934] 2 WWR 459 (Sask CA) where the Saskatchewan Court of Appeal came to the opposite conclusion. That is, they held that the application for leave was not sufficient to bring the execution within the limitation period. 
In Manitoba Hydro Electric Board v John Inglis $\mathrm{Co}^{153}$ under the Manitoba discoverability rules, a plaintiff can apply for leave to commence an action within 12 months of when he or she becomes aware of the elements of the claim outside the specific limitation period. In this case, the plaintiff commenced the leave application within the requisite 12 months, but because of procedural delay, the leave application was not heard until the expiration of the ultimate limitation period. The trial judge held that the relevant date for determining whether the ultimate limitation period had lapsed was the date of the order granting leave, and not the date when the application for leave was filed. Thus, the application for leave was dismissed as time-barred under the ultimate limitation period. This was overturned on appeal, as the Manitoba Court of Appeal was "unable to accept that the legislature intended the [complainant] to be without remedy in such circumstances."154 The Court expressed further concerns about defendants defeating claims by causing procedural delays. ${ }^{155}$ Thus, the Manitoba Court of Appeal held that leave should not be granted where an application for leave is made after the expiration of the ultimate limitation period. ${ }^{156}$

A similar approach was taken in Potter $v$ Banks ${ }^{157}$ where Justice Johnson held that "the first step in the process to obtain ... leave is a 'proceeding'” as the taking of such a step shows that the plaintiff does not intend to sleep on its rights. ${ }^{158}$ Justice Johnson stated that "[t]o hold otherwise would work grievous injustice in some circumstances."159

In Ontario, the courts have consistently held that when a motion for leave is filed to add a new defendant or cause of action, the filing of the motion is sufficient to bring the new claim within the limitation period. ${ }^{160}$ This is because (1) the date that the motion is heard is not entirely within the plaintiff's control; and (2) the defendant or potential defendant is on notice of the claim against him or her from the date of the motion. ${ }^{161}$

These holdings are consistent with the four purposes or rationales underlying the limitation acts in that the filing of the application puts the defendant on notice that the plaintiff intends to enforce its rights. Additionally, the plaintiffs cannot be said to be "sleeping on their rights" if the leave application is brought within the limitation period. Lastly, such holdings do not result in unfairness to the plaintiff where the claim becomes time-barred as a result of procedural delay or appeal even though the plaintiff has acted diligently in pursuing his or her rights.

A few cases suggest that the filing of the application for leave may not be sufficient to bring the action within the limitation period. However, in these cases, it appears that the courts were simply following a statutory procedure or did not turn their minds fully to the

[1996] 4 WWR 547 (MBCA).

Ibid at para 20.

Ibid at para 23.

Ibid at para 22.

[1971] SJ no 92 (QL) (QB).

Ibid at para 8.

Ibid.

See Moss v Joseph Brant Memorial Hospital (2004), 10 CPC (6th) 1 (Ont Sup Ct) [Moss]; Wong v Sherman, [1998] 78 ACWS (3d) 688 (Ont Ct J (Gen Div)). This also seems to be the approach in Alberta. See Cartwright v Cartwright Canada Inc, 2007 ABQB 189, 156 ACWS (3d) 778.

Moss, ibid at paras 26, 33-38. 
issue. For example, in Newfoundland (Minister of Justice) $v$ Fowler ${ }^{162}$ the application for leave was filed on the date of the expiration of the limitation period. The limitation provision prescribed that no action could be brought against the Minister of Justice after the expiration of one year from the date on which the cause of action arose. The Newfoundland Court of Appeal considered whether it was appropriate to extend the limitation period so that the plaintiff could file the claim against the Minister of Justice. ${ }^{163}$ If the application for leave was akin to bringing the action, there would be no need to extend the limitation period. Similarly, in Re Dependent Adults Act, ${ }^{164}$ it appears that Justice Dea did not treat the filing of the leave application itself as sufficient to bring the plaintiff within the limitation period. In this case, Justice Dea, out of an abundance of caution, ordered the public trustee to apply for leave and then granted the leave application as the limitation period was set to expire within a few days of the application to determine which party would represent the dependant adult. ${ }^{165}$ If the leave application itself was sufficient, there would have been no hurry or concern.

\section{APPLiCATION OF THE GENERAl PRINCIPLES TO DERIVATIVE ACTIONS}

While the courts have not considered directly whether the filing of the leave application is sufficient to bring the derivative action within the limitation period, a few derivative action cases suggest that the filing of the application was insufficient to bring the derivative action within the limitation period and that some additional step was required.

In Carr, the defendants brought an interlocutory application seeking to dismiss the plaintiff's oppression remedy and derivative action. The shareholder was granted leave to commence a derivative action on 24 May 2005; a writ of summons was filed for the derivative action on 18 November 2005; and on 28 March 2006 a statement of claim was filed in the derivative action. ${ }^{166}$ The claims against the defendant in the derivative action were based in fraud, negligence, and breach of duty in managing the corporation. A majority of this conduct related to the corporation's dealings with an alleged affiliated entity in 1998. As a result, the limitation period of six years expired some time in 2004. In discussing the limitation period, the Court noted that "[t]he Derivative Action was not commenced until November 18, 2005 [when the writ of summons was filed], more than six years after the claims arose and were known to the [Plaintiffs]." 167 Accordingly, Justice Rice did not consider the leave application to be sufficient to commence proceedings.

In Winfield $v$ Daniel, ${ }^{168}$ the defendants argued that leave to commence the derivative action should be postponed until the oppression action was resolved. The shareholder argued

(1993), 107 Nfld \& PEIR 311 (Nfld CA).

It is likely that this holding is based on the wording of the statute in that in the second stage the plaintiff is required to "bring and maintain an action" against the Minister. As such, the statute itself indicates that the application for leave, or the first stage, is not sufficient to bring the claim within the limitation period.

(1983), 43 AR 81 (QB).

Ibid at para 22.

Carr, supra note 59 at para 34 (the judgment did not indicate when the application for leave was filed, although the oppression action was commenced on 31 May 2004).

Ibid at para 105.

2004 ABQB 40, 352 AR 82 [Winfield]. 
that waiting could cause irreparable harm since the limitation period might expire. Justice Gallant accepted this argument and granted leave to bring the derivative action. Thus, implicitly, both the shareholder and Justice Gallant must not have believed that the filing of the application for leave was sufficient to bring the derivative action within the limitation period. But again, this point was not specifically decided. The findings in Carr and Winfield are inconsistent with the courts' treatment of leave applications in other situations and they are inconsistent with the principles underlying limitation periods.

\section{STATUTORY INTERPRETATION}

The filing of the application for leave should be considered a sufficient act to fall within the language of "seek a remedial order." The term "remedial order" is defined as "a judgment or an order made ... in a civil proceeding requiring a defendant to comply with a duty or to pay damages for the violation of a right."169 This phrase is broad and should be given a corresponding broad interpretation.

The phrase “remedial order" has been considered in procedural contexts besides situations outside bringing a typical statement of claim or originating application. Case law currently conflicts as to whether the taxation process is an application for a remedial order under the Limitations Act, or whether something more is required. In Macleod Dixon LLP v Fazal, ${ }^{170}$ the plaintiffs argued that because taxation was a prerequisite to ultimately obtaining judgment, the taxation certificate should be treated as a remedial order. Master Waller concluded that a taxation certificate was not a remedial order or an application for a remedial order because under the rules it was not an order or judgment of the court and nothing could be done with it without further court intervention. ${ }^{171}$ This finding was upheld on appeal.

In contrast, in Sharma $v 643454$ Alberta Ltd, ${ }^{172}$ Justice Slatter concluded that "[a]ppointment for [t]axation [was] an application for a remedial order because the very purpose of it [was] to obtain an enforceable judgment against the client." 173 Justice Slatter determined that a "functional and pragmatic approach" was warranted to the interpretation of "seek a remedial order" since the Limitations Act does not use traditional legal terminology such as "issue a statement of claim.” ${ }^{174}$ As a result, Justice Slatter determined that the mere fact that enforcement proceedings were started by an appointment of taxation rather than by way of statement of claim did not make a difference. ${ }^{175}$ Finally, Justice Slatter determined that the purpose and rationales behind the Limitations Act were met by treating the appointment for taxation as conduct sufficient to bring the taxation matter within the limitation period. ${ }^{176}$ 
In Avramenko v Laurich \& Associates, ${ }^{177}$ Master Hanebury referred to Macleod Dixon and Sharma. She did not prefer one case over another but rather recognized that Sharma provided the plaintiff an argument that her appointment for taxation may have been sufficient conduct for her claim to not be statute-barred. Ultimately, the issue as to whether an appointment for taxation was sufficient to "seek a remedial order" within the limitation period was left unresolved since the plaintiff was required to obtain leave before the appointment was set and she failed to do so.

The interpretation of "seek a remedial order" in Sharma should be adopted as the preferred approach since it is consistent with the principles of statutory interpretation that limitation periods attach a strict interpretation and any ambiguity should be resolved in favour of the person whose rights are being truncated. ${ }^{178}$

Based on the reasoning in Sharma, the actions required to "seek a remedial order" should also include the filing of the leave application in derivative actions since the only purpose of obtaining the leave is to proceed with a claim against the wrongdoers and ultimately obtain judgment. ${ }^{179}$ The cases that treat "seek a remedial order" as synonymous with starting an action or commencing a proceeding are reading restrictions into the provision which do not exist. The phrase "commence proceedings" is well-known, and if the legislature intended limitation periods to be satisfied by the filing of a statement of claim, it would have used such language. Finally, section 2(1) of the Limitations Act includes both the phrases "proceedings commenced" and "seek a remedial order" which further indicates that the two phrases have different meanings.

In summary, the filing of the leave application should be considered sufficient conduct to bring the derivative action within the limitation period as this is consistent with how a majority of cases already treat leave and notice requirements in other contexts. It is also consistent with a functional and pragmatic approach to the interpretation of "to seek a remedial order."

\section{B. Seeking Leave as a Condition Precedent}

If an application for leave is not itself considered an act sufficient to bring the corporation within the limitation period, the corporation could be left without a remedy as a result of procedural delay or appeal. Once the leave application is filed, it could be said that its resolution is a condition precedent to commencing the action. ${ }^{180}$ That is, once the leave

1772006 ABQB 489, 405 AR 355.

178 Berardinelli v Ontario Housing Corp, [1979] 1 SCR 275 at 280.

179 Where leave to commence a derivative action or derivative remedies are sought in an oppression action, the filing of the oppression statement of claim should be considered the conduct that brings the derivative action within the limitation period for the same reasons. It gives the defendant notice of the claims against him or her, and it cannot be said that the plaintiff is sleeping on his or her rights.

180

Examples of conditions precedent are found in insurance legislation or insurance policies and require the insured to do certain acts before he or she can file a claim against the insurer. In Peixeiro $v$ Haberman, [1997] 3 SCR 549 at para 34, Justice Major referred to the requirements under the discoverability rule as conditions precedent. In this context, a condition precedent refers to any procedural requirement that must be satisfied before the actual claim is filed. 
application is filed, the limitation period is suspended until the final resolution of the leave application.

In Costello $v$ Calgary (City of), ${ }^{181}$ the Alberta Court of Appeal considered the interplay of the two-year limitation period and a municipal statute which stated that an action for damages could not be commenced until one month after the associated bylaw, which gave rise to the damages, had been formally quashed. In 1972 the City of Calgary purported to pass a bylaw expropriating the plaintiffs land. In 1976 the plaintiff sued the city for a declaration that the bylaw was invalid. While the lower courts upheld the bylaw, in 1983 the Supreme Court of Canada held that the bylaw was invalid. In 1985, two years to the day after the Supreme Court of Canada decision, the plaintiff sued the city for damages.

Justice Côté held that the damages claim was not time-barred. While he did not endorse explicitly the characterization of the municipal provision as a condition precedent, he did state that "if [an] analogy must be used, a statutory condition for suit should postpone the start of limitation periods." 182 It appears that Justice Côté preferred the rationale provided by other Canadian jurisprudence: a limitation period begins to run when the plaintiff has an immediate right to institute and maintain his or her action ${ }^{183}$ or when the rights to institute an action accrued to the plaintiff. ${ }^{184}$ Specifically, he stated that as a matter of policy in tort law, it was better to have a limitation period that started to run very late as opposed to one which may expire before the plaintiff could sue. ${ }^{185}$ Since the plaintiff was statutorily barred from suing the city until one month after the Supreme Court decision, the limitation period did not commence until 1983.

A similar result can be found in Gulliver v Canadian Broadcasting Corporation, ${ }^{186}$ where on the facts it was practically impossible for the plaintiff to give notice under the statute and file the statement of claim within the limitation period. Under the Crown Liability Act, ${ }^{187} \mathrm{a}$ plaintiff was required to give the Canadian Broadcasting Corporation (CBC) 90-days notice of its intention to sue. Under the Newfoundland Defamation Act, ${ }^{188}$ a plaintiff was required to sue within three months of the defamation occurring. In the interests of fairness, the Newfoundland Court of Appeal held that "[t]he right of action has appended to it the obligation to give 90 days notice." ${ }^{\prime 189}$ As a result, the plaintiff was required to sue no more than three months after giving the CBC notice as long as the notice was given within the 90 day period. ${ }^{190}$

A review of the American jurisprudence on the relationship of limitation periods and notice periods shows a similar approach. For instance, in Barchett $v$ New York Transit

(1989), 97 AR 348, leave to appeal to SCC refused, 21643 (27 October 1989) [Costello].

Ibid at para 22.

Ibid at para 25.

Ibid at para 23.

Ibid at para 21.

(1998), 71 Nfld \& PEIR 1 (Nfld CA) [Gulliver v CBC].

RSC 1970, c C-38.

SN 1983, c C-63.

Gulliver v CBC, supra note 188 at para 21.

Ibid at para 41. 
Authority, ${ }^{191}$ the plaintiff was required to file a notice within 90 days after the claim arose. The limitation period at the time was one year. Under special circumstances, a plaintiff could be granted leave to serve a late notice outside that 90 -day period but still within the one year limitation period. In this case, the plaintiff filed for leave to extend the 90-day notice period within a few days of the limitation period expiring. Leave was granted outside the one year limitation period. The New York Court of Appeal held that the statute of limitations was tolled from the time the plaintiff commenced the proceeding to obtain leave until the order granting leave took effect. ${ }^{192}$ A similar result was reach in Re Hickman ${ }^{193}$ where the New York Court of Appeal concluded that the "petitioner was entitled to a toll of the limitations period to commence her wrongful death action against the Motor Vehicle Accident Indemnification Corporation during the period the Court was considering her application for leave to file a late notice of claim."194

In summary, both the condition precedent theory and the argument that the limitation period does not commence until the plaintiff can actually bring the claim support the position that the limitation period should be suspended from when the leave application is filed until the issue of leave is conclusively resolved. ${ }^{195}$ Both theories resolve the practical problem and injustice that would otherwise arise if a complainant faces procedural delays or when an appeal of the leave application causes the actual filing of the statement of claim to be outside the limitation period.

\section{CONCLUSION}

Canadian and American jurisprudence illustrates that the application of limitation periods to derivative actions is not a straightforward exercise. Two main issues arise, namely; who is the claimant for the purposes of limitation periods, and how do limitation periods apply to leave applications?

The application of the discoverability principle to derivative actions is problematic because of additional issues that arise, including: (1) the distinction between the de facto plaintiff and the de jure plaintiff; (2) the rules governing when knowledge will be imputed or attributed to a corporation; and (3) whether the situation is different when the wrongdoers are negligent as opposed to engaged in self-dealing.

Currently, the Canadian courts avoid many of these additional issues by assuming that the knowledge of the complainant, or de facto plaintiff, is relevant for the purposes of determining discoverability. This approach is consistent with the approach taken in the State of Delaware. A majority of US jurisdictions, however, have adopted the majority test of the adverse domination doctrine, which holds that so long as the majority of the board is

NY (2d) 1 (Ct App 1967).

Ibid at 6.

75 NY (2d) 975 (Ct App 1990).

Ibid at 975 .

Where the derivative action is a remedy in an oppression action, the limitation period should be tolled from when the oppression statement of claim is filed to when the leave issue is resolved conclusively for the same reasons 
comprised of wrongdoers, the limitation period is tolled for the purposes of a derivative action against the wrongdoers. This doctrine holds that a corporation is not imputed with the knowledge of directors and officers acting adversely to it. This doctrine also recognizes the separate corporate existence principle by not attributing the knowledge of the shareholder to the corporation. This should also be the preferred approach in Canada since it is consistent with the separate corporate existence principle. In addition, certain rationales underlying the operation of limitation periods, namely the discoverability principle and that a plaintiff should not be time barred from bringing an action for inherently unknowable harm, is also consistent with the majority test of the adverse domination doctrine. Further, the adverse domination doctrine, particularly when applying the majority test, is also consistent with the Canadian principles governing when knowledge will be attributed or imputed to the corporation. Finally, it recognizes that limitation periods are substantive rules and, as such, should be determined from the perspective of the corporation, the de jure plaintiff.

The application of limitation periods to derivative actions also causes a practical problem given its two-stage process. While derivative action cases have failed to consider this point, a review of the Canadian jurisprudence in other actions suggests the filing of the leave application, the first of the two-stage process, is sufficient to bring the derivative action within the limitation period. For instance, the Alberta Court of Queen's Bench in Sharma provides support for the argument that an application for leave is sufficient to "seek a remedial order" as it starts a chain of events leading to a judgment. These cases illustrate the unfairness that can arise where the leave application is delayed or appealed and the complainant and corporation are blameless.

As an alternative argument, the limitation period should be suspended from the time that the leave application is filed to the final resolution of the leave application. Support for this position can be found in treating the resolution of the leave application as a condition precedent to the derivative action, or in the rationale that time should be suspended until such time as the plaintiff can initiate and carry the action.

Both of these issues have not yet been addressed properly by the Canadian judiciary. Furthermore, it seems the current approach of the Canadian judiciary too often relies on unarticulated assumptions that, if taken to their logical conclusion, appear to conflict with the purposes and rationales underlying limitation periods, derivative actions, and the separate corporate existence principle.

When the Canadian judiciary has its next opportunity to review limitation periods in the context of derivative actions, it should no longer gloss over such concerns but should actively engage in the issues. In doing so, the Canadian judiciary should unequivocally adopt the adverse domination doctrine, apply the majority test, and explicitly hold that the filing of the leave application is sufficient to bring the derivative action within the limitation period. This clarity is required to provide certainty and predictability to the adjudication of derivative action claims. 